\title{
Quality of Some Kids Meals and Its Adequacy FOR THEIR NUTRIENTS' REQUIREMENTS
}

\author{
By \\ Emad M. El-Kholie \\ Department of Nutrition \& Food \\ Science, Faculty of Home Economics, \\ Menufiya Univ. \\ Ghada M. El-Kherbawy \\ Department of Food Science, Home \\ Economics Division Faculty of \\ Agriculture, Cairo Univ. \\ Magda I. Hassan \\ Department of Food Science, \\ Home Economics Division Faculty of Agriculture, Cairo Univ.
}

\section{Research Joupnal Specific Education \\ Faculty of Specific Education \\ Mansoura University}

ISSUE NO. 27, OCTOBER. 2012

$$
\text { مجلة بعوث التربية النوعية ـ جامعة المنصورة }
$$


Quality of Some Kids Meals and Its Adequacy for Their Nutrients' Requirements $L=$ 


\title{
Quality of SOME Kids Meals and Its Adequacy for THEIR NUTRIENTS' REQUIREMENTS
}

\author{
Emad M. El-Kholie* Ghada M. El-Kherbawy \\ Magda I. Hassan ${ }^{* *}$
}

Abstract

The availability of foods high in fat and energy dense through fast foods (FF) or taking away restaurants was associated with the poor quality diet. The main aim of the present investigation was directed to assess the proximate composition of FF meals and its nutritional contribution to dietary quality of children as one of the most vulnerable group of population. Two brands of worldwide chain happy meals (beef and chicken burgers were evaluated for the proximate composition, i.e. moisture, protein, total lipids, ash and fiber. Carbohydrates \& energy values were calculated. Contribution of these meals was compared with children's daily recommendations.

Chemical composition of happy meals showed that, beef burger from second chain recorded the lowest percent of moisture (36.70\%) and protein $(15.70 \%)$. However, the other three meals had close percentages (41.40 $42.23 \%$ ) from moisture, chicken burger from second chain scored the highest percent from protein (19.12\%). Although, the percent of fiber (5.63$7.00 \%)$ revealed poor content, all happy meals were considered highly energy dense $(565.88-588.36 \mathrm{~K}$.cal). They also had very high percent from fat (40.32-43.76\%). Neglected difference was observed between meals from ash contents (1.32-1.85\%).

Regarding nutrients adequacy, the percentage of energy was covered by the four meals ranging between 30 - more than $50 \%$ of needs of children from 2 - 11 years old. Chicken burger from second chain had the lowest

\footnotetext{
* Department of Nutrition \& Food Science, Faculty of Home Economics, Menufiya Univ.

${ }^{* *}$ Department of Food Science, Home Economics Division Faculty of Agriculture, Cairo Univ.
}

\section{5}


values of energy requirements due to its weight compared with other meals. Happy meals contribution exceeded the requirements of children at 1-3 years old (129.9- 146.2 \% of protein AMDR). These percentages were 49.7 $55.9 \%$ at $9-13$ years old $\& 88.9$ - $100 \%$ for children from 4 - 9 years. With regard to fat contribution from happy meals all children (in the three age categories 1-3, 4-9 and 9-13 years) could be got more than their needs . Children got approximately one fifth to one third of their needs of carbohydrates when they consumed one happy meal. While, they have one tenth to one quarter of their needs from fiber from this meal. 


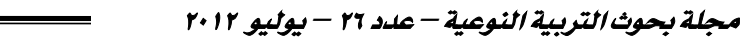

Quality of Some Kids Meals and Its Adequacy for TheIR NUTRIENTS' REQUIREMENTS

\author{
Emad M. El-Kholie" \\ Ghada M. El-Kherbawy ${ }^{* *}$
}

Magda I. Hassan ${ }^{* *}$

\title{
Introduction
}

Eating habits are shaped early in life. Healthy habits formed during childhood and carried into adulthood decrease the future risk for chronic disease (Mikkelsen and Chehim 2007).

The busy and hectic lifestyle has opened the way for fast food industry in many countries around the world. Fast foods, ready to eat, firstly were introduced with hotdog and hamburger food stands. Nowadays, it became a multibillion dollar industry that has widespread influence on what and how people eat. A strong criticism of fast food industry was extensively reported by Schlosser (2002).

The widespread of fast foods restaurants and the exponential growth of that industry have been associated with increased obesity (Periera et al., 2005 and Niemeir et al, 2006, Mohr et al., 2007 and Ebbeling et al., 2007 and Connor Gober et al., 2007), heart disease, type 2 diabetes, high blood pressure and high cholesterol (American heart Association 2010).

Fast Food meals have high energy \& saturated fat dense and low micronutrient content (Blair et al, 2005; Schimidt et al., 2005; Harnack and French, 2005and Astrup, 2005). Its consumption was associated with other poor food choices such as low vegetable and milk intake (Boutelle et al, 2007).

Children are entering the consumer marketplace by increasingly younger ages. They are the target of millions of dollars worth of food advertising. This increasing focus on children as consumers may be affecting the quality of their diets. The child food market notably includes

\footnotetext{
* Department of Nutrition \& Food Science, Faculty of Home Economics, Menufiya Univ.

${ }^{* *}$ Department of Food Science, Home Economics Division Faculty of Agriculture, Cairo Univ.
} 
frozen dinners aimed at 3- 10 year olds and other child-specific meals (Mikkelsen and Chehim 2007).

The present study was conducted to determine proximate chemical composition of happy meals available in Egyptian markets (Worldwide chains of FF restaurants) and evaluate its nutritional contribution to children's requirements. This study will provide information that satisfies the consumer needs to ensure quality of such foods.

\section{MATERIALS \& METHODS}

\section{Sampling:}

A total of four types of happy meal samples (40 for each) were brought from two local wholesale markets of worldwide fast food chains located (1 and 2) at Cairo City, Cairo Governorate. No condiments (Ketchup or mayonnaise, mustard, pepper sauce or topping were requested). Two meals were chicken burgers and the others were beef burgers [(Chicken Happy Meal 1, 2(CHM1\& CHM2 ) and Meat Happy Meal 1,2 (MHM1 \& MHM2)]. All meals were served with French fries.

On purchase foods were wrapped in greaseless paper and packed in carton boxes. Samples were packed in polyethylene bags and put into an ice box and transported to Faculty of Agriculture laboratory, Cairo University. Meals code, description, weight and its source were illustrated in Table (1).

Table 1: Meals code, description, weight and its source.

\begin{tabular}{||c|c|c|c||}
\hline $\begin{array}{c}\text { Meal } \\
\text { code }\end{array}$ & Meal description & $\begin{array}{c}\text { Meal } \\
\text { weight } \\
(\mathrm{g})\end{array}$ & $\begin{array}{c}\text { Fast food } \\
\text { restaurant } \\
\text { chain }\end{array}$ \\
\hline \hline MHM1 & Small beef burger sandwich and French fries & 180 & 1 \\
\hline CHM1 & Small chicken burger sandwich and French fries & 180 & 1 \\
\hline MHM2 & Small burger sandwich and French fries & 170 & 2 \\
\hline CHM2 & Small beef burger sandwich and French fries & 154 & 2 \\
\hline
\end{tabular}




\section{Chemical analysis:}

Moisture, Protein, fat, fiber and ash were determined according to A. O. A. C. (2005). Total carbohydrates content including fiber was calculated according to FAO (1982) by difference as follows:

$\%$ carbohydrates $=100-(\%$ moisture $+\%$ protein $+\%$ ash $+\%$ fiber $)$.

Estimated energy values were calculated by multiplying amount of protein and carbohydrates by 4.0 and fat by 9.0 .

\section{Cholesterol Content}

The amount of cholesterol was determined by spectrophotometric method at $490 \mathrm{~nm}$ as reported by Park, 1999.

\section{Nutrient adequacy:}

The percentages of RDA from carbohydrates, fat, protein \& fiber were computed for children aging (1-3, 4-8 and 9-13) years of both sexes by the following equation:

Amount of nutrient in whole happy meal / nutrient requirement $* 100$

The same equation was used to calculate the percentage of energy of children aging 3-11 years for males \&females.

Fat and protein were computed as Acceptable Macronutrient Distribution Range (AMDR).

Fiber was computed as AI (the mean intake). While, there is no recommended daily allowance, or $\mathrm{RDA}$, for cholesterol, the federal government suggests that adults limit their intake to less than $300 \mathrm{mg}$ a day, according to Dietary Guidelines for Americans 2005.

\section{RESULTS \& DISCUSSION}

Chemical composition of happy meals is shown in Tables (2) and (3). It could be noticed that the moisture contents of happy meals ranged from 36.70 to $42.23 \%$. The lowest moisture content was seen for MHM2 sample (beef burger meal), while the highest was found for MHM1. Slight variations were observed among the percent of moisture contents in the other samples. 


\section{Quality of Some Kids Meals and Its Adequacy for Their Nutrients' Requirements $L=$}

The chicken happy meal 2 was highest percentage of protein (19\%). The values of fat were very closed. While, percentages of carbohydrates and fiber ranged from 30.1-35.04, 5.63-7.(Table 2).

Table (2): Chemical composition of happy meals (on dry weight basis)

\begin{tabular}{|c|c|c|c|c|c|c|c||}
\hline $\begin{array}{c}\text { Sample } \\
\text { code }\end{array}$ & $\begin{array}{c}\text { Protein } \\
\%\end{array}$ & $\begin{array}{c}\text { Fat } \\
\%\end{array}$ & $\begin{array}{c}\text { CHO } \\
\%\end{array}$ & $\begin{array}{c}\text { Fiber } \\
\%\end{array}$ & $\begin{array}{c}\text { Ash } \\
\%\end{array}$ & $\begin{array}{c}\text { Estimated } \\
\text { energy } \\
(\text { K.cal })\end{array}$ & $\begin{array}{c}\text { Cholester } \\
\text { ol }(\mu \mathrm{g} / \mathrm{g})\end{array}$ \\
\hline \hline MHM1 & 18.28 & 43.76 & 30.35 & 6.21 & 1.40 & 588.36 & 1.5 \\
\hline CHM1 & 16.90 & 42.15 & 34.00 & 5.63 & 1.32 & 582.95 & 2.9 \\
\hline MHM2 & 15.70 & 40.32 & 35.04 & 7.00 & 1.85 & 565.88 & 1.4 \\
\hline CHM2 & 19.12 & 43.13 & 30.10 & 6.25 & 1.40 & 585.05 & 1.7 \\
\hline
\end{tabular}

With respect to chemical composition on wet weight in table 3 , about one quarter of samples was fat, $10 \%$ of them was protein. While, carbohydrate percentages were ranged from $17.53-22.22$.

Table (3): Chemical composition of happy meals (on wet weight basis).

\begin{tabular}{||c|c|c|c|c|c|c|c||}
\hline $\begin{array}{c}\text { Sample } \\
\text { code }\end{array}$ & $\begin{array}{c}\text { Moisture } \\
(\mathrm{g})\end{array}$ & $\begin{array}{c}\text { Protein } \\
(\mathrm{g})\end{array}$ & $\begin{array}{c}\text { Fat } \\
(\mathrm{g})\end{array}$ & $\begin{array}{c}\text { CHO } \\
(\mathrm{g})\end{array}$ & $\begin{array}{c}\text { Fiber } \\
(\mathrm{g})\end{array}$ & $\begin{array}{c}\text { Ash } \\
(\mathrm{g})\end{array}$ & $\begin{array}{c}\text { Cholesterol } \\
(\mu \mathrm{g} / \mathrm{g})\end{array}$ \\
\hline \hline MHM1 & 42.23 & 10.56 & 25.28 & 17.53 & 3.59 & 0.81 & 0.86 \\
\hline CHM1 & 42.08 & 9.79 & 24.41 & 19.70 & 3.26 & 0.76 & 1.67 \\
\hline MHM2 & 36.70 & 9.94 & 25.52 & 22.22 & 4.43 & 1.10 & 0.88 \\
\hline CHM2 & 41.40 & 11.20 & 25.27 & 17,67 & 3.66 & 0.83 & 0.99 \\
\hline
\end{tabular}

Table 4 shows amounts of nutrients in whole happy meals. The highest content of protein was MHM from the first chain and the lowest content of it was MHM from the second chain, although they were meat happy meal. Despite the relatively high percent of protein content of happy meals, there is a broader impact that they might have on overall diet. Beef and chicken burger protein have been replaced by binders and fillers to cut cost (Babji et al., 2000).

Slight differences were noticed among the percentages of fiber, ash contents of the investigated FF meals. 
There is a convergence in the amount of fat in meals for each chain according to type. The amount of carbohydrates in happy meals varies from 46.35 - $61.2 \mathrm{gm}$. The last meal (CHM2) had the lowest values of almost nutrients especial fiber and energy, that is due to low weight.

All happy meals were very high in fat and calories. The estimated energy of them meals showed high values ranging from 585.05 to 565.88 calories provided from $100 \mathrm{~g}$ of happy meal. This could be related to the existence of French fries beside high fat contents of the used ingredients as well as the preparation techniques.

In this respect, O'Donnell et. al.,( 2003) found that subjects who reported eating fast food had significantly $(\mathrm{P}<0.001)$ higher intake of energy, fat, saturated fat, sodium and lower intake vitamins A \& $\mathrm{C}$ than those who did not reporting eating fast food.

The high fat and calories contents of FF meals under study assured those previously noted by (UW Health, 2003 and Hurley \& Liebman, 2005).

While there is no recommended daily allowance, or RDA, for cholesterol, the federal government suggests that adults limit their intake to less than 300mg a day, according to Dietary Guidelines for Americans 2005.

Table (4): Nutrient contents of happy meals

\begin{tabular}{||c|c|c|c|c|c|c|c|}
\hline $\begin{array}{c}\text { Sample } \\
\text { code }\end{array}$ & $\begin{array}{c}\text { Samples } \\
\text { weights }\end{array}$ & $\begin{array}{c}\text { Protein } \\
(\mathrm{g})\end{array}$ & $\begin{array}{c}\text { Fat } \\
(\mathrm{g})\end{array}$ & $\begin{array}{c}\text { CHO } \\
(\mathrm{g})\end{array}$ & $\begin{array}{c}\text { Fiber } \\
(\mathrm{g})\end{array}$ & $\begin{array}{c}\text { Energy } \\
(\mathrm{K} . \mathrm{cal})\end{array}$ & $\begin{array}{c}\text { Cholesterol } \\
(\mathrm{mg})\end{array}$ \\
\hline \hline MHM1 & 180 & 19.00 & 78.77 & 54.63 & 11.18 & 611.78 & 1.55 \\
\hline CHM1 & 180 & 17.62 & 75.87 & 61.20 & 10.13 & 607.77 & 3.02 \\
\hline MHM2 & 170 & 16.89 & 68.54 & 59.57 & 11.90 & ฯ.9,1 $\varepsilon$ & 1.51 \\
\hline CHM2 & 154 & 17.24 & 66.42 & 46.35 & 9.63 & orv,90 & 1.53 \\
\hline
\end{tabular}

From figure 1 to figure 7 show the percentages of RDA of calories content for males and females from 2- 11 years old. It could be noticed that:

- The percentage was of energy covered by the four meals ranging between 30 - more than $50 \%$ of needs of children from 2 - 11 years old. 
- In younger ages, the daily needs of energy were lower. Therefore, the meals gave higher proportion of energy needs.

- Due to increase energy needs of males from females, the proportion of meals energy which gives for males less than females.

- Last meal (CHM2) gives less values of the energy requirements due to low weight of it for the other meals.

From above the happy meal gave children huge amount of energy. That's meaning high energy intake at one meal was followed by low energy intake at the next meal, or vice versa (Birch et. al., 1991). children who regularly eat fast food consume more calories overall and eat fewer fruits and vegetables than children who do not go to fast food restaurants as often (Active Living Research, 2005).

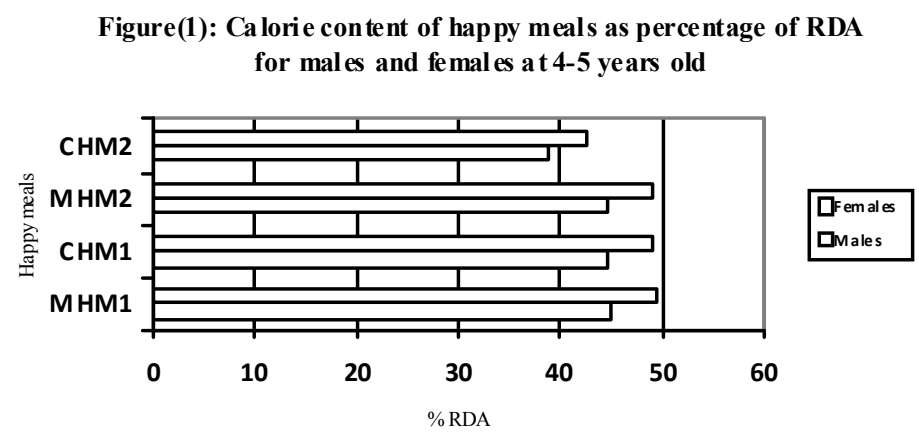

Figure(2): Calorie content of happy meals as percentage of RDA for males and females at 5-6 years old

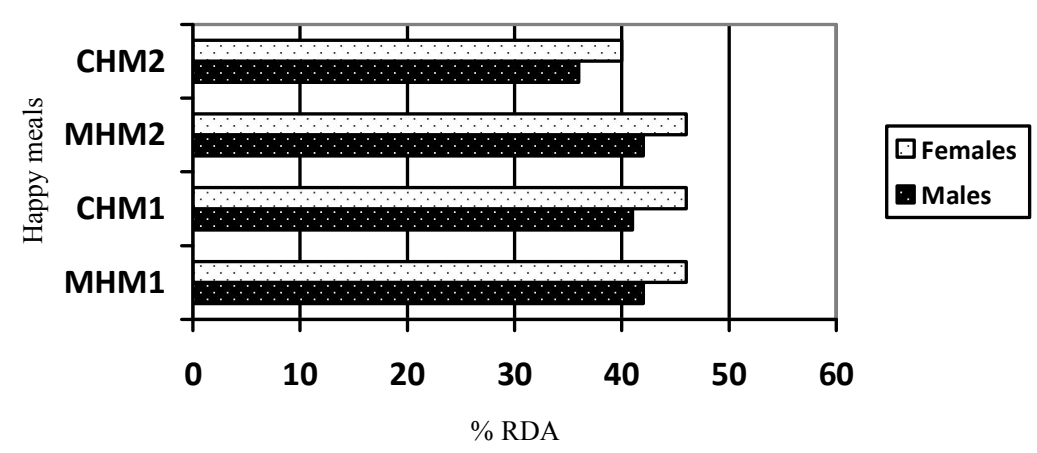




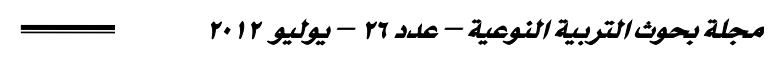

Figure(3): Calorie content of happy meals as percentage of RDA for $m$ ales and females at 6-7 years old

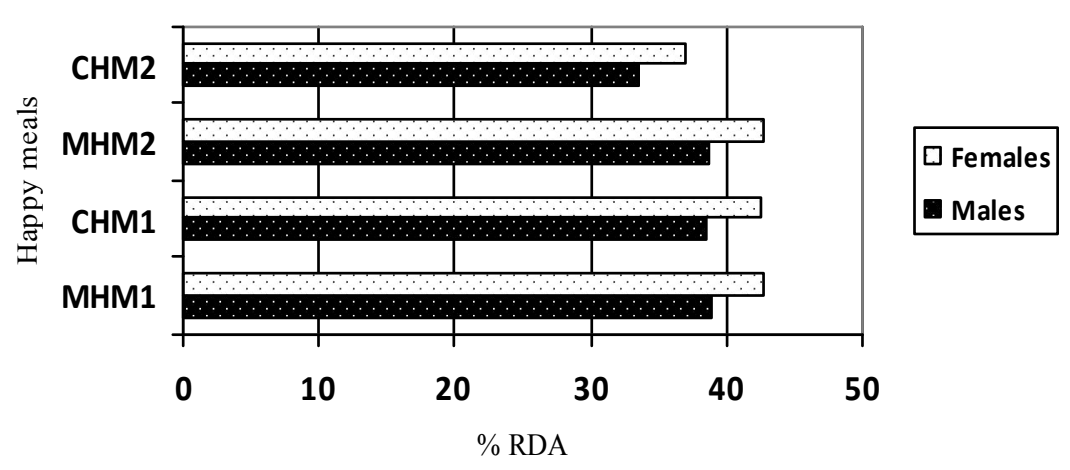

Figure(4): Calorie content of happy meals as percentage of RDA for males and females at 7-8 years old

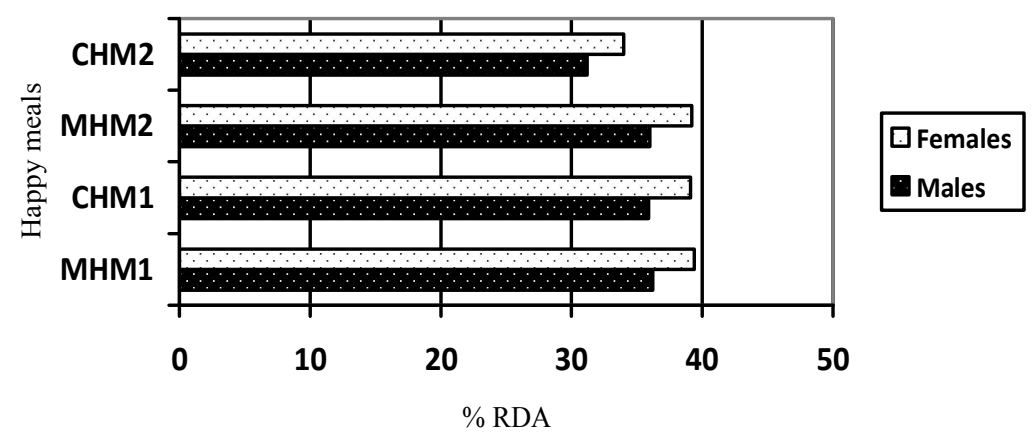

Figure(5): Calorie content of happy meals as percentage of RDA for males and females at 8-9 years old

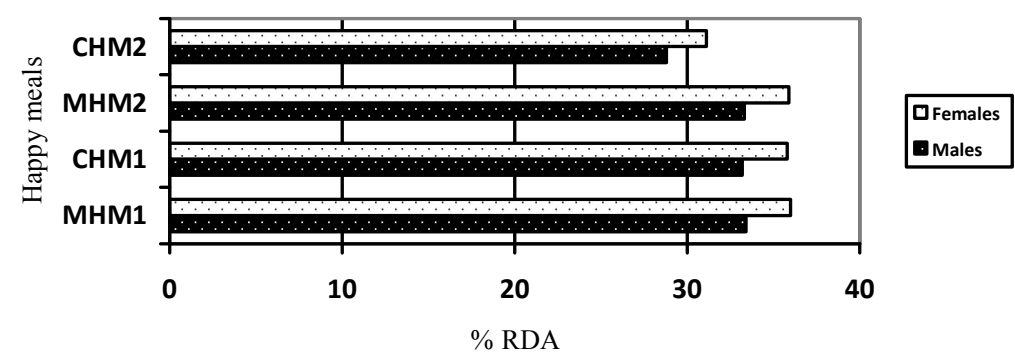


Figure(6): Calorie content of happy meals as percentage of RDA

for males and females at 9-10 years old

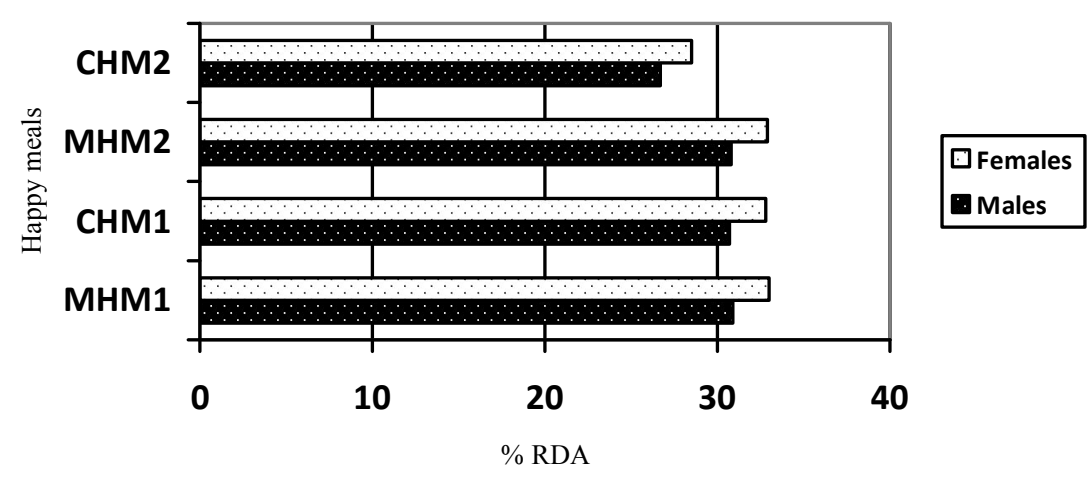

Figure(7): Calorie content of happy meals as percentage of RDA for males and females at 10-11 years old

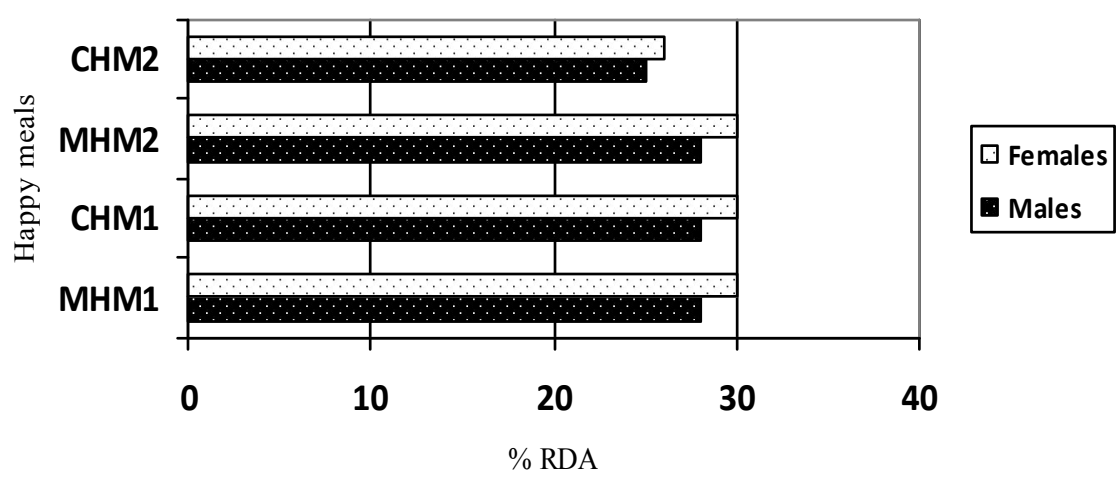

The percentage of protein contents of happy meals covering children's needs at different ages ( 2 - 11 years old) were assessed and illustrated in table 5. Happy meals contribution exceeded the requirements of children at 1-3 years old (129.9- $146.2 \%$ of protein AMDR). These percentages were $49.7-55.9 \%$ of protein AMDR at 9-13 years old. with respect to children from 4 - 9 years might get $88.9-100 \%$ of their needs of protein if they ate one happy meal of under study. The primary organ tasked with filtering excess protein from the body are the kidneys. As protein is broken down in the body any protein that is not needed is broken down into toxic products 
such as ammonia and urea. These toxic byproducts of excessive protein intake can cause inflammation in the kidneys, which may manifest as back pain. Also excess protein intake can also take calcium away from the bones. Over time, this loss of calcium can leave the bones weakened and encourage the development of osteoporosis (Fass,2010).

Concerning fat contribution of happy meals to fat requirements, fat contents were compared to children AMDR form 1- 13years old (Table 5). All children (in the three categories 1-3, 4-9 and 9-13 years ) could be got more than their needs. For child aged between 1-3 years it may get 111.2 $130 \%$ of fat needs. While, any child aged from $4-13$ years ate one happy meal, get $129.7-151.7 \%$ of fat needs.

In this respect, Schroeter (2004) found that the readily available high fat foods ,e.g. fast food meal, was less healthy than food at home, since it tends to contain more total fat and saturated fat, less calcium, fiber, and iron, and fewer servings of fruits and vegetables.

With regard to carbohydrates and fiber, children get approximately one fifth to one third of their needs of carbohydrates when they consumed one happy meal. While fiber, children get one tenth to one quarter of their needs of fiber when they consumed happy meal.

In this subject, UCLA university, 2005 reported that fiber increases satiety (the feeling of fullness) by adding bulk to foods without additional calories. This may reduce the risk of obesity and the severity of diabetes. Diets rich in cereal fiber reduce the risk of stroke (Ascherio et al, 1998). 
Quality of Some Kids Meals and Its Adequacy for Their Nutrients' Requirements L

Table (5): Adequacy of nutrients as percentages of requirements for children in different ages.

\begin{tabular}{|c|c|c|}
\hline$\overbrace{\% \mathrm{RDA}}^{\text {Age }}$ & $4-9$ years & $9-13$ years \\
\hline \multicolumn{3}{|l|}{$\mathrm{CHO} 1$} \\
\hline$\%$ of RDA for MHM1 & 24.3 & 24.3 \\
\hline$\%$ of RDA for CHM1 & 27.3 & 27.3 \\
\hline$\%$ of RDA for MHM2 & 29.1 & 29.1 \\
\hline$\%$ of RDA for $\mathrm{CHM} 2$ & 20.9 & 20.9 \\
\hline \multicolumn{3}{|l|}{ Fat $2 \mathrm{a}$} \\
\hline$\%$ of AMDR for MHM1 & 151.7 & 151.7 \\
\hline$\%$ of AMDR for CHM1 & 146.4 & 146.4 \\
\hline$\%$ of AMDR for MHM2 & 144.6 & 144.6 \\
\hline$\%$ of AMDR for CHM 2 & 129.7 & 129.7 \\
\hline \multicolumn{3}{|l|}{ Protein } \\
\hline$\%$ of AMDR for MHM1 & 100.0 & 55.9 \\
\hline$\%$ of AMDR for CHM1 & 92.7 & 51.8 \\
\hline$\%$ of AMDR for MHM2 & 88.9 & 49.7 \\
\hline$\%$ of AMDR for CHM2 & 90.7 & 50.7 \\
\hline Fiber $3^{*}$ & & Males/Females \\
\hline$\%$ of $\mathrm{AI}$ for MHM1 & 14.4 & $11.6 / 13.8$ \\
\hline$\%$ of $\mathrm{AI}$ for $\mathrm{CHM} 1$ & 13.0 & $10.5 / 12.5$ \\
\hline$\%$ of $\mathrm{AI}$ for MHM2 & 17.7 & $14.3 / 17.0$ \\
\hline$\%$ of $\mathrm{AI}$ for $\mathrm{CHM} 2$ & 14.6 & $11.8 / 14.1$ \\
\hline
\end{tabular}

1 all values of carbohydrates RDA in all age categories are $130 \mathrm{gm}$.

2 values of fat AMDR in (1-3) and (4-13) age categories are $35 \& 30 \mathrm{gm}$ respectively.

3 values of fiber AI in 9-13 for males and females are different 31 and 26 gm respectively.

It represents Recommended Dietary Allowances (RDAs) in bold type, Adequate Intakes (AIs) in ordinary type followed by an asterisk $(*)$. RDAs 
and AIs may both be used as goals for individual intake. RDAs are set to meet the needs of almost all (97 to 98 percent) individuals in a group. For healthy breastfed infants, the AI is the mean intake. The AI for other life stage and gender groups is believed to cover the needs of all individuals in the group, but lack of data prevent being able to specify with confidence the percentage of individuals covered by this intake.

Acceptable Macronutrient Distribution Range (AMDR)a is the range of intake for a particular energy source that is associated with reduced risk of chronic disease while providing intakes of essential nutrients. If an individual consumed in excess of the AMDR, there is a potential of increasing the risk of chronic diseases and insufficient intakes of essential nutrients.

SOURCE: Dietary Reference Intakes for Energy, Carbohydrate. Fiber, Fat, Fatty Acids, Cholesterol, Protein, and Amino Acids (2002/2005). This report may be accessed via www.nap.edu 
Quality of Some Kids Meals and Its Adequacy for Their Nutrients' Requirements $[=$ REFERENCES

- A.O.A.C. (2003). Official Methods of the Association of Official Analytical Chemists. Arlington, Virginia, U.S.A.

- Active Living Research (2005): Investigating policies and environments to support active communities. Designing to Reduce Childhood Obesity . http://www.activelivingresearch.org/files/childhoodobesity021105.pdf.

- American heart Association (2010): Understanding childhood obesity. http://www.heart.org/idc/groups/heartpublic/@wcm/@fc/documents/downloadab le/ucm_304175.pdf

- Ascherio,A.; Rimm,E.B.; Hernán,M.A.; Giovannucci,E.L.; Kawachi,I.; Stampfer, M.J. and Willett, W.C.(1998). Intake of potassium, magnesium, calcium, and fiber and risk of stroke among us men. Circulation, 98: 1198-1204.

- Astrup, A. ( 2005). Super sized and diabetic by frequent fast food consumption, Lancet, 365, 4-5.

- Babji, A.S.; Nuri, M.N.; Suherman, J. and Serichempaka, M.Y. (2000). Quality Assessment of Local and Franchise Beef and Chicken Burgers, PertanikaJ. Trap. Agric. Sci. 23(2): 103 - 112.

- Birch, L. L.; Johnson, S. L.; Andresen, G.; Peters, J. C. and Shulte, M. C. (1991). The variability of young children's energy intake.N Engl J Med, 324, 232-235.

- Blair Lewis, L.; Sloane, D.C.; Nascimento, L.M.; Diamant, A.L.; Guinyard, J.J.; Yancey, A.Y.; Flynn, G. (2005) .African Americans' access to healthy food options in south Los Angeles restaurants. Am. J. Public. Health 95, 668-672.

- Boutelle, K.N.; Fulkerson, J.A.; Neumark-Sztainer, D.; Story, M.; French, S. (2007). Fast food for family meals: relationships with parents and adolescent food intake; home food availability and weight status. Public Health Nutr., 10, 16-23.

- Connor Gorber, S.; Trembly, M.; Moher, D.; Gorber, B. (2007). A comparison of direct vs. self-report measures for assessing height, weight and body mass index: a systematic review. Obesity Reviews

- Dietary Guidelines for Americans (2005). http://www.health.gov/dietaryguidelines/dga2005/document/default.htm

- Ebbeling, C. B. ; Garcia-Lago, E. ; Ledig, M. M. ; Seger-Shipee, L. G. ; Feldman, H. A. and Ludwig, D. S. (2007): Altering portion sizes and eating rate 
to attenuate gorging during a Fast Food meal; effects on energy intake. Pediatrics, 119, 869-875.

- Fass,B.(2010): Are there any side effects from taking protein?

- Food and Agriculture Organozation "FAO." (1982): Food Composition Tables For The Near East, FAO., Food and Nutrition Paper, p. 26.

- Harnack, L.and French, S.( 2005). Fattening upon fast food. J. Am. Diet Assoc., 103, 1296-1297.

- http://www.dining.ucla.edu/housing_site/dining/SNAC_pdf/FactsOfFiber.pdf.

- http://www.livestrong.com/article/213575-are-there-any-side-effects-fromtaking-protein/\#ixzz1 xD6Idf.

- http://www.livestrong.com/article/244493-what-is-the-rda-forcholesterol/\#ixzz1 xiRu5KQX.

- Hurley, J.and Liebman, B.(2005).Fast food in '05 Nutrition Action health letter, Center for Science in the Public Interest,12-15.

- Lorna K. Fraser 1,* Kimberly L. Edwards 2, Janet Cade 3 and Graham P. Clarke 1(2010).The Geography of Fast Food Outlets: A Review, Int. J. Environ. Res. Public Health 2010, 7, 2290-2308

- McGlynn, A.(2011). What is the RDA for cholesterol?.

- McGraw-Hill (2003): Year book of Science \& Technology. The McGraw-Hill Companies, Inc.

- Mikkelsen, L. and Chehimi, S.(2007). The Links Between the Neighborhood Food Environment and Childhood Nutrition. Prevention Institute Oakland, Calif, Robert Wood Johnson Foundation, http://old.preventioninstitute.org/pdf/FoodEnv11.07.pdf

- Mohr, P. ; Wilson, C. ; Dunn, K. ; Brindal, E. and Wittert, G. (2007): Personal and lifestyle characteristics predictive of the consumption of Fast Food in Australia. Public Health Nutr., 10, 1456-1463.

- Niemeir, H.M.; Raynor, H.A.; Lloyd-Richardson, E.E.; Rogers, M.L.; Wing, R.R. ( 2006). Fast Food consumption and breakfast skipping: predictor of weight gain from adolescence to adulthood in anationally representative sample. J. Adolesc. Health, 39, 842-849.

- O’Donnell, S.H.; Hoerr,S.L.; Mendoza, A.J. and Goh, E.T.(2008). Nutrient quality of fast food kids meals. Am J Clin Nutr,88:1388 -95. 
- Park, Y.W. (1999) :Cholesterol contents of U.S. and imported goat milk cheeses as quantified by different colorimetric methods .Small Ruminant Research, 32: 77-82.

- Periera, M.A.; Kartashov, A.I.; Ebbeling, C.B.; Van Horn, L.; Slattery, M.L.; Jacobs, D.R.; Ludwig, D.S. (2005). Fast Food habits, weight gain, and insulin resistance (the CARDIA study):15 year prospective analysis. Lancet, 365, 36-42.

- Schimidt, M.; Affenito, S.G.; Striegal Moore, R.; Khoury, P.R.; Barton, B.; Crawford, P.; Kronberg, S.; Schreiber, G.; Obarzanck, E.; Daniels, S. (2005). Fast Food intake and diet quality in black and white girls. Arch. Pediatr. Adolesc. Med., 159, 626-631.

- Schlosser, E. (2002). Fast Food Nation: The Dark Side of the All-American Meal. Harper Perennial.

- Schmidt, M.; Affenito, S.G.; Striegal Moore, R.; Khoury, P.R.; Barton, B.; Crawford, P.; Kronberg, S.; Schreiber, G.; Obarzanck, E.; Daniels, S. (2005). Fast Food intake and diet quality in black and white girls. Arch. Pediatr. Adolesc. Med., 159, 626-631.

- Schroeter, C. (2004). Relating diet, demographics and lifestyle to increasing US obesity rates. Agrarwirts schaft, 53 (8): 328-333.

- Ucla University(2005): Fiber facts.

- UWHealth(2003). Nutrition Care for You, University of Wisconsin Hospital and Clinics Authority Board. 